\title{
DE CALÍMACO A TINTÍN: SOBRE EL USO DE LA RECUSATIO EN UN POEMA DE LUIS ALBERTO DE CUENCA
}

\author{
FROM CALLIMACHUS TO TINTÍN: THE USE OF RECUSATIO IN A POEM \\ WRITTEN BY LUIS ALBERTO DE CUENCA
}

\section{Facundo GIMÉNEZ}

Celehis-Conicet facugimenez@gmail.com

Resumen: El siguiente trabajo tiene como objetivo analizar la presencia de la figura de la recusatio o de la forma apologética, entendida como una modalidad programática, en el poema "Línea clara” (2006) del escritor madrileño Luis Alberto de Cuenca (1950). Para ello se analizarán, en principio, las particularidades de dicha figura retórica, para luego dar cuenta de las formas en que la tradición grecolatina clásica se hace presente en la poesía española del posfranquismo y en particular en nuestro poeta. El análisis de dicha recusatio, al mismo tiempo, habilitará la lectura de una importante franja de la última poesía española.

Palabras clave: Luis Alberto de Cuenca; poesía; recusatio.

Abstract: The present article analyzes the presence of the recusatio figure in the poem "Linea clara" (2006), written by the Spanish writer Luis Alberto de Cuenca (1950). Throughout the present work, the basic characteristics of this rhetorical figure will be analyzed to develop how the classical Graeco-Latin tradition appears in the Spanish poetry after the democratic transition and particularly in de Cuenca's work. The study of the recusatio will also enable an interpretation of the path followed by some nowadays-Spanish poetry.

Key words: Luis Alberto de Cuenca; poetry; recusatio. 


\section{reve recorrido por la recusatio}

La recusatio es una figura retórica cuya estabilización se da en la poesía alejandrina y que posee un recorrido amplio en la tradición literaria occidental ${ }^{1}$. Según la fórmula acuñada por Calímaco, en el prólogo de los Aitía, la recusatio consistiría en el rechazo de una forma poética por la elección de otra. En general, la negativa parece referirse al epos heroico, en favor de otros géneros y temáticas menores, como los amorosos. Sin embargo, lo que resulta una constante es que la negativa a ejecutar un tipo de poesía implica necesariamente la ponderación de otra, o al menos su vindicación. En el texto de Calímaco, del que conservamos solamente fragmentos, la recusatio implicaba un tono polémico, que enfrentaba la forma breve — propia de la escuela alejandrina-, al Gran Poema de inspiración homérica (Calímaco, 1980, p. 11). En dicho texto ${ }^{2}$, conocido como Respuesta a los Telquines, Calímaco se defiende de las acusaciones («de mí, de mi poesía, murmuran los “Telquines”») de no haber compuesto una obra de largo aliento («en millares» de líneas) y contrariamente a su edad avanzada, de haber cultivado su «verso parcamente, como un niño». El gran poema épico es rechazado porque, para Calímaco, evidentemente la extensión no puede ser un parámetro para juzgar una obra: « [juzgad] por su arte la poesía y no por leguas persas»]. Al mismo tiempo, el poema, como lo harán por lo general las recusationes, merodeará los límites del arte poética. Calímaco en La respuesta a los Telquines, efectivamente, habrá de describir su interpretación de la poesía. Para ello se servirá de una escena inaugural en la que es el propio Apolo quien se le presenta al poeta para guiar su proyecto creador:

\footnotetext{
Pues en la ocasión incluso la primera en que dispuse la plana en mis rodillas, ya me dijo Apolo Licio:

«...la víctima, buen cantor, bien cebada (has de criarla), pero sutil tu Musa.

También (te) ordeno esto: hollar por donde no pasan los carros; (llevar el tuyo) no por rodadas comunes al resto de las gentes, no por camino llano sino por sendas ( $\sin$ trillar), aun cuando tengas que conducir por una más angosta».
}

La predilección por una musa que califica como sutil ${ }^{3}$ y la elección de un camino poco transitado coinciden con el proyecto de los Aitía, en los que se evitan los grandes temas heroicos y en los que el

\footnotetext{
${ }^{1}$ El esquema de la recusatio es sumamente antiguo. Uno de los antecedentes más remotos es el del poeta Estesícoro, quien en el siglo VI a. C. escribió el siguiente fragmento: «Musa, deja las guerras a un lado, y canta conmigo / las bodas de los dioses y los banquetes / de los hombres y las fiestas de los felices...» (Ferraté, 1996, p. 189). Aunque sumamente breves, los restos del poema muestran claramente el abandono de la temática heroica en favor de motivos más festivos.

${ }^{2}$ Utilizamos la versión perteneciente al libro Los epigramas literarios de Calímaco de Máximo Brioso (1987, pp. 123-127).

3 Ángel Casas Agudo indica que el texto de Calímaco se encarga de distanciarse de diversas formas con respecto a la poética de sus enemigos literarios, de quienes además se burla llamándolos "Telquines". Calímaco aprovecha para resaltar sus diferentes ideas sobre lo que ha de ser la nueva poesía, mediante conceptos, metáforas y términos que luego consagra en el prólogo de su obra magna: «La Envidia habló furtivamente al oído de Apolo: / "no me gusta el aedo cuyo canto no es como el mar ". / Apolo rechazó a la Envidia con el pie y dijo así: /"grande es la corriente del río Asirio, pero arrastra en sus aguas muchos lodos y muchas inmundicias. / A Deo no le llevan las abejas agua de cualquier procedencia, / sino el
} 
poeta se inclina más bien por una serie de argumentos menores. Al mismo tiempo, la falta de un hilo conductor o de un tema único rompe la idea del conjunto y la variedad temática se extiende como regla (de Romilly, 2016, p. 276) Es que, tal como plantea el filólogo Gregorio Hinojo Andrés, las recusationes son un pretexto formal utilizado por el poeta para exponer su concepción de la poesía, la que él cultiva y le interesa de manera especial, y sus diferencias con la poesía épica y con otros géneros poéticos, por lo que pueden considerarse poemas programáticos de crítica literaria (1985, p. 94).

Otro desplazamiento que detecta Hinojo Andrés está vinculado con el tipo de poesía que rechaza la recusatio. Como también podemos observar en la Respuesta a los Telquines, la exposición programática que acaba realizando la forma apologética se opera a partir de una descripción y, por momentos, reescritura de aquello de aquello que se está rechazando. De este modo, no es extraño que el rechazo del epos heroico adopte, paradójicamente, un tono épico, hecho que afirma la solidez de la elección, que no se produce por la incapacidad del poeta. Es en este sentido, que detecta una cercanía de la recusatio con otra figura retórica, la praeteritio, que consiste en afirmar que se pasa por alto, no se sabe o no se quiere decir lo que en realidad se está diciendo. Es, precisamente, el uso de esa figura en el caso de las recusationes lo que habilita la exposición de contenidos y temas épicos, de hazañas y gestas, con el fin de anunciar que no los desea cantar, que su musa no se lo aconseja o que su ingenio es inadecuado para temas tan elevados (Hinojo Andrés 1985: 94).

En el periodo augusteo, la recusatio calimaquea es recuperada con un matiz diverso, propio de las condiciones de producción de la época. Por entonces, la recusatio romana se encuentra claramente relacionada a la insistente presión de Mecenas, que alentaba a los poetas a escribir textos épicos celebrando las hazañas de Augusto. Ernst Bickel explica esta insistencia en el hecho de que, al igual que Polión y Mesala, Mecenas se propuso con gran empeño la tarea de cohonestar la poesía con la fundamentación literaria del orden nuevo augústeo:

Después de la batalla de Accio, Mecenas sugirió simultáneamente a Horacio, Virgilio, Vario y Propercio, celebrar los hechos de Agripa y Octaviano, y resucitar para Roma a Ennio en forma nueva. En esta tarea no se escatimó ninguna seducción como lo prueba la donación a Vario por Augusto de un millón de monedas de plata por su tragedia Thyestes que compuso en memoria del triunfo del año 29. Los poetas debieron de enzarzarse en luchas internas por estos intentos de granjearse el favor de Mecenas. (Bickel 1982: 194)

Arturo Alvárez Hernández, por su parte, explica que durante el periodo augusteo es posible apreciar en muchos poetas herederos del legado neotérico, como Virgilio u Horacio, un cambio de actitud respecto del epos heroico y, de manera más general, respecto de la escritura cívicamente comprometida. Este cambio de actitud produce que el motivo de la recusatio se modifique y que se acerque a otra figura como la de la excusatio, en la que el poeta se declara atraído por la idea de celebrar hazañas heroicas, pero confiesa su incapacidad actual y remite a un momento futuro esa posibilidad. La excusatio augustea tiene muchos puntos en común con la apologética de Calímaco, pero difiere por

pequeño chorro que mana, sin mancha y puro, / de la fuente sacra: la suprema delicia”». El canto épico es equiparado al mar o a un río caudaloso y todo ello equivale a la impureza — poética - del lodo y del limo. Por el contrario, la nueva poesía - elegíaca-, frente al río/mar-épico, es un pequeño chorro no sucio, sino puro e inmaculado, que por tanto ha de brotar de una pequeña fuente sagrada.(Casas Agudo, 2009) 
lo menos en un punto fundamental, que es el de admitir la superioridad del arte capaz de celebrar las grandes gestas del mito y de la historia ${ }^{4}$ (Álvarez Hernández 1997: 24).

Horacio presenta algunas recusationes sumamente interesantes para comprender este matiz del periodo augusteo. En la Oda VI, el poeta se excusa de escribir las hazañas militares de Marco Vipsanio Agripa («Agripa, nada en mí, para ese canto existe.» 26: vv), proponiendo para dicha empresa al poeta Lucio Vario Rufo ${ }^{5}$ («Vario, rival del Cisne del poema meonio/ — de Homero— sólo puede cantar la fortaleza / de las victorias tuyas...» 26: vv. 1-3). Horacio, en principio, se justifica por su incapacidad y por el temor de una empresa de dicha magnitud ( «El poder de la Musa y el miedo, al par, me niegan / tal honor a la lira» 26: v. 10). Finalmente, acaba por decantarse por la temática amorosa:

Libre de amor, yo canto los convites y riñas de doncellas que arañan con uñas recortadas a mancebos amantes. $\mathrm{O}$ canto los amores en que me abraso y quemo, sí, contra mi costumbre, estoy enamorado de amores verdaderos (Romero y Cordero 1955: 26; vv.16-17).

La oda XII, por su parte, insiste en la excusación del tema heroico, esta vez indicando la mejor adecuación de la prosa de su destinatario, Mecenas, para narrar las hazañas de Augusto ("Mejor que yo, en mi verso, / Mecenas, tú, en tu prosa" 91: vv.16-17). De nuevo, el texto termina indicando la predilección de la musa del poeta por los temas amorosos ("Mi Musa, en tanto, las loanzas dulces / dirá de tu Lycimnia, / la reciprocidad de sus amores/ con los amores de ella... 91-92: vv. 22-25). Las primeras estrofas, por otra parte, muestran claramente cómo es el dispositivo de la enunciación que propone la forma apologética:

Ni las ferocidades de la guerra al pie de la Numancia sin murallas, ni la dureza del terrible Aníbal, ni la púrpura líquida de sangre, en que la sangre de África trueca el mar de Sicilia, cantaré, citaredo.

No cantaré, tampoco,

ni el impulso brutal de los Lapitas,

\footnotetext{
${ }^{4}$ Víctor Agustín Sequeiros en su artículo "Horacio y la recusatio de la elegía amorosa" (2009) explica, además, que la proliferación de estas dos figuras responde a la preocupación por adquirir una precisa ubicación genérica que caracterizó desde temprano a los poetas augusteos, atentos observadores de los ejemplos alejandrinos. Sequeiros se suma a quienes proponen una diferencia entre recusatio y excusatio que transcribimos a continuación por su claridad: «La recusatio implica en general una declaración de incapacidad y un rechazo liso y llano para escribir en una especie o en un género solicitado ajeno al del poeta, o bien en un tema o materia extraña al género o a la especie literaria en cuestión. La excusatio, por su parte, consiste en un rechazo moderado en el que el poeta reconoce una cierta atracción por el género en el que es invitado a poetizar, en la mayoría de los casos el épico, pero, aduciendo una incapacidad presunta o real, posterga su aceptación hacia un futuro incierto o bien pretende derivar el encargo hacia otro escritor en condiciones de enaltecerlo.»(Sequeiros 2009: 48)

${ }^{5}$ Horacio lo llama «águila del canto meonio», en referencia a Homero por ser también poeta épico. Ernst Bickel explica que salvo el nombre, «Carmen epicum de actis Caesaris et Agrippae», no se conserva nada de su epopeya: «Vario, cuando, llevado de su sentimiento amistoso publicó la Eneida de Virgilio, después de la muerte de éste, aprovechando el manuscrito que dejó, enterró la propia epopeya» (Bickel 1982: 448). Más allá de esta mención, referida a su desempeño como poeta épico, Vario Rufo es conocido por su festejada obra trágica, en la que se destaca Thyestes del año 29.
} 
ni las locuras del Centauro Hyleo,

ni la temeridad de los Gigantes,

que hicieron vacilar, de abajo a arriba,

la casa de Saturno,

antes de ser vencidos

por la pujanza de Hércules (Romero y Cordero 1955: 91: vv. 1-15).

Las dos primeras estrofas poseen una estructura sintáctica similar, encabezada por una negación referida a la elección de la temática épica, tanto en su aspecto histórico (primera) como en su aspecto mitológico (segunda). Ahora bien, lo que llama la atención es la amplitud de esa negación, su extensión y su precisión para aquello que, sin embargo, no va a ser cantado. En efecto, como se dijo antes, la voz del poeta, para excusarse del epos heroico, debe adquirir una dicción épica. Al mismo tiempo, tal como explica Soledad Pedernera, el fragmento presenta una serie de sutilezas que vinculan cada episodio heroico, veladamente, con la figura de Augusto:

\footnotetext{
El lugar prominente dentro de la historia romana dado a la bella Numantiae puede vincularse a la recusatio de Lucilio que Horacio parece seguir, pero también puede pensarse en la batalla de Cantabria librada por Augusto en el 26 a. C, que lo asemejaría a Escipión. Si Numancia posee un nivel alusivo, también Hannibalem puede sugerir una relación con la africana Cleopatra y la batalla de Actium. Con respecto a los temas míticos, el pequeño sumario (batalla entre Lapitas y Centauros; Hércules; los Gigantes, Saturno) similar a los catálogos helenísticos, opera igualmente con el nivel alusivo del lenguaje a la manera de una praeteritio más que de una narración, en la cual Hércules y Saturno parecen aludir a Augusto y al antiguo régimen (Pedernera 2011: 73).
}

Este juego de ambigüedades refuerza la enunciación de la excusatio, en un complejo equilibrio entre lo estético y lo político. Del modo en que al negarse a la temática heroica, alcanza una dicción épica que acaba demostrando su propia aptitud poética, la forma apologética le permite a Horacio cumplir con el mandato de Mecenas y al mismo tiempo incumplirlo. El uso de esta figura en Horacio, por lo tanto, es una muestra bastante evidente de que la presentación de un programa estético implica una serie de expectativas, de adversarios y de contrapropuestas. Podríamos arriesgar que tanto la recusatio calimaquea como la excusatio horaciana, en este sentido, admiten una construcción contextual del arte poético e indagan un espacio en el que puede instalarse y hallar su propia legitimidad.

Esta breve revista permite apreciar la insistencia de la forma apologética a través de los años. Su gran versatilidad le ha permitido, por un lado, derivar hacia otras formas como la excusatio, según las condiciones de producción, como queda claro en el periodo augusteo, y por otro lado, funcionar como vehículo de la teorización poética por parte de los autores, como queda evidenciado en la vertiente calimaquea. Además, es importante destacar que la recusatio habilita un espacio diverso al de las artes poéticas, en el cual la enunciación metapoética parece amenazada por una posición adversaria. Este tipo de enunciación, de tono evidentemente polémico, por lo tanto, impone la construcción de una destinación múltiple, en la que la forma elegida debe justificarse a partir del enfrentamiento a otra de signo contrario.

A continuación observaremos el uso de la recusatio en el poema "Línea clara" (2006) de Luis Alberto de Cuenca. Para ello en principio, será necesario explicar la inclinación hacia las formas 
De Calímaco a Tintín: sobre el uso de la recusatio en un poema de Luis Alberto de Cuenca

clásicas que se insinúan en los años ochenta y que en los noventa, cuando es escrito el poema, ya es una regularidad en el panorama español. La forma apologética que ejecuta Luis Alberto de Cuenca no solamente significará una remisión hacia la tradición alejandrina, que ha estudiado con detenimiento, sino además una forma de arte poética que se inserta en un contexto bastante definido.

\section{Luis Alberto de Cuenca y la recuperación del universo clásico}

Luis Alberto de Cuenca publica su primer libro, Los retratos, en 1971, en la estela de la generación poética del 68 , que tuvo su impulso fundamental en la antología barcelonesa Nueve novísimos poetas españoles (1968) prologada por José María Castellet. Su primer libro —así como también los dos que le siguieron: Elsinore en 1972 y Scholia en 1976- acompañaron la acometida de una generación que en las postrimerías del franquismo iría adentrándose en una exploración del lenguaje poético por fuera de cualquier compromiso de orden político, reavivando en el plano de la producción literaria un experimentalismo que recuperaba las vanguardias, el arte pop y el decadentismo. Es por esa época, para ser exactos en 1976, cuando el poeta madrileño da a conocer su tesis de doctorado sobre el poeta helenístico Euforión de Calcis, que en consonancia con su propia producción poética se caracterizaba por su marcado hermetismo y erudición. Durante la década de los ochenta su producción adquirirá un giro que lo ubicará en el centro de la nueva escena poética que comienza a insinuarse con la llegada de la democracia en 1982. En su libro Necrofilia (1983) puede observarse un alejamiento, aunque no completo, de las formas herméticas que caracterizaban su obra previa. La Caja de plata de 1984 será el pilar en el que se asentará toda su producción posterior, delimitando los rasgos definitivos de una poesía que se extiende hasta la actualidad. Claridad expositiva, tono coloquial, humor, culturalismo de cita interna, elaboración epigramática, recuperación de moldes tradicionales y de temáticas universales, serán algunas de las constantes en la obra del poeta madrileño desde entonces.

Este cambio de signo de la poesía de Luis Alberto de Cuenca se encuentra estrechamente vinculado con un cambio de paradigma operado a partir de la Transición democrática (1977-1982), que pone sobre la superficie una presencia cada más acentuada de la tradición clásica en las producciones poéticas. Ofrenda a la memoria (1976) de José Gutiérrez, Transparencia indebida (1977) de Francisco Bejarano; Alma del tiempo (1978) de Luis Martínez, Primera despedida (1978), de Fernando Ortiz; Cielos e inviernos (1979), de Ramón Irigoyen; Mitos (1979), de Abelardo Linares, Las cosas que me acechan (1979), de Víctor Botas, y Los devaneos de Erato (1980), de Ana Rossetti son los primeros indicios de esta inclinación que termina de consolidarse en la década de los ochenta. La insistencia de esta línea estética, es apuntada por Antonio de Villena quien en 1992 señala el "sesgo clásico” de la última poesía española. Eugenio D’Ors cinco años después, por su parte, ratifica los dichos de Villena cuando afirma que «el rasgo que caracteriza primordialmente a la mayoría de los libros interesantes publicados en España por poetas jóvenes desde los últimos años setenta hasta esta segunda mitad de los noventa es la recuperación del sentido clásico» (d’Ors 1997). D’Ors entendía 
que dicha recuperación no era solamente acercamiento a la tradición, a partir de aspectos formales o temáticos, sino también a partir de la concepción humanista de la poesía, la confianza en el poder comunicativo del lenguaje, la conciencia y la aceptación de sus límites, la sobriedad y contención expresivas y el equilibrio entre el contenido y la forma, entre los elementos intelectuales, emocionales y sensibles, y entre la realidad objetiva y la subjetiva. Estos rasgos propuestos por d'Ors pueden aplicarse sin mayores cambios a la producción de Luis Alberto de Cuenca, que por entonces — sin perder el erudito andamiaje mitológico y tradicional que había caracterizado su obra previaabandona completamente la experimentación con el lenguaje y se vuelca a una escritura sobria y de moldes tradicionales, que apuesta a la ampliación de un público lector, a partir del uso de la dicción coloquial, de la tematización de la experiencia y, por momentos, de la búsqueda del efecto humorístico.

Otro aspecto que habría que tener en cuenta en esta recuperación del sentido clásico en la poesía española es el que observa Luis Bagué Quílez. El crítico catalán sostiene que a medida que este neoclasicismo tiende a afianzarse es posible apreciar una evidente inclinación al pastiche irónico y el revival imitativo (Bagué Quílez, 2003, p. 29). Además, detecta un desplazamiento de la tradición clásica hacia una actitud sentimental que aspira a conmover al lector a través de la concentración de la intensidad emotiva. Los apuntes familiares y cotidianos, la importancia de la temporalidad, el lenguaje coloquial y el retorno al verso clásico blanco o a la métrica tradicional son rasgos inherentes a esta nueva forma de plasmar el discurso poético. Del mismo modo, el mundo clásico no se conecta sólo con la reconstrucción del pasado grecolatino. A veces puede actualizarse mediante la aproximación a la vida contemporánea, como en la poesía neocostumbrista, o abstraerse hacia un corolario filosóficomoral, como en la renovación de la tópica literaria (Bagué Quílez, 2003, pp. 39-40). Esta conexión con el mundo clásico puede observarse en gran parte de la obra de Luis Alberto de Cuenca. Poemas como "Helena Palinodia"6 (1996), que reescribe el célebre fragmento de Estesícoro, en una actualización burlesca o, Jano $(1984)^{7}$ en el que la recuperación de la mitología latina implica una reflexión moderna sobre la multiplicidad del sujeto, dan muestra de este aspecto.

\section{En busca de la "Línea clara"}

La recuperación de tradición clásica de la obra luisalbertiana, además, puede verse en la recurrencia de ciertos motivos, tropos y procedimientos de origen grecolatino. En particular, habría

\footnotetext{
${ }^{6}$ «No, no es verdad, amor, aquella historia. / No llegó a seducirte aquel imbécil / de rizos perfumados. No te fuiste / precipitadamente de la fiesta / de nuestro aniversario, con los ojos / clavados en el bulto que emergía / de entre sus piernas, y con las narices / saturadas de droga. No embarcaste / en su yate de lujo con lo puesto / — que casi no era nada-, mientras yo / te buscaba en la calle como un loco, / creyendo que te había pasado algo. No desapareciste de mi vida / como una exhalación y para siempre. / No puede ser verdad aquella historia. »(de Cuenca 2006: 337)

7 «Dices que solo soy Enrique Jekyll / y que no existe fórmula en el mundo / capaz de convertirme en Mr. Hyde. / Cuando pasen los días o los años, / cuando el tiempo nos lleve a otras hogueras, / hacia otra plenitud u otro desastre, / imagíname entonces, imagina / los rasgos de mi cara, reconstruye / lo que tu hielo convirtió en cenizas. / Y en la memoria esquiva de tu frío,/ en el recuerdo de tu lejanía, / Eduardo Hyde seré, y por un instante / me amarás, aunque yo ya esté muy lejos; / y será hermoso, pues por un instante /yo seré tu tristeza, y no los otros.»(de Cuenca 2006: 176)
} 
que señalar su confesada cercanía al alejandrinismo ${ }^{8}$, que puede constatarse no solamente en su actividad como traductor de la obra de Calímaco y de la Antología Palatina, entre otros textos de la misma raigambre, sino además en su predilección por las formas epigramáticas. Es por esta razón que no resulta casual que encontremos, en una de las pocas artes poéticas que nos ofrece en más de cuarenta años de producción, una forma apologética o recusatio en uno de los poemas pertenecientes a La vida en llamas (2006). Nos referimos a la "Línea clara", que a continuación transcribimos:

\section{LÍNEA CLARA}

Dicen que hablamos claro, y que la poesía no es comunicación, sino conocimiento, y que sólo conoce quien renuncia a este mundo y a sus pompas y obras - la amistad, la ternura, la decepción, el fraude, la alegría, el coraje, el humor y la fe, la lealtad, la envidia, la esperanza, el amor, todo lo que no sea intelectual, abstruso, místico, filosófico y, desde luego, mínimo, silencioso y profundo-. Dicen que hablamos claro, y que nos repetimos de lo claro que hablamos, y que la gente entiende nuestros versos, incluso la gente que gobierna, lo que trae consigo que tengamos acceso al poder y a sus premios y condecoraciones, ejerciendo un servil e injusto monopolio.

Dicen, y menudean sus fieras embestidas. Defiéndenos, Tintín, que nos atacan. (2006: 13)

Este poema, pese a pertenecer, como ya se dijo, a un libro publicado en 2006, tiene como contexto de producción la década de los noventa y en particular una disputa entre dos corrientes que habían estado en pugna por casi medio siglo, la de la poesía entendida como conocimiento y la de la poesía entendida como comunicación, en la que la última se encuentra asociada con la recuperación del clasicismo observada en el apartado anterior. Este desfasaje entre la fecha de escritura y la fecha de publicación, queda al descubierto en una entrevista que ofrece el propio Luis Alberto de Cuenca, en la que además explica el origen onírico del texto:

En verano de 1994 tuve un sueño: soñé que me encontraba en peligro de muerte y que Tintín me salvaba (había estado leyendo a lo largo de las vacaciones los álbumes de Tintín a mi hija todos los días un ratito, antes de dormirse). Literaturicé el salvamento tintiano en un poema titulado "Línea clara" [...] un poema que ha visto la luz recientemente en mi libro La vida en llamas y en el que se habla en un plural meramente poético... (Cuenca: 2007: 65).

Este retraso en la publicación del texto, de más de una década, puede deberse a varias razones. La primera es la poca adecuación al tono de sus dos libros anteriores Por fuertes y fronteras (1996) y Sin miedo ni esperanza (2002). La segunda, que nos resulta más plausible, es su participación en la

\footnotetext{
${ }^{8}$ En una entrevista que tuve la posibilidad de realizarle en 2016 y que se encuentra todavía en prensa, Luis Alberto de Cuenca confesaba su preferencia por el alejandrinismo: «Mucho más que Euforión —una especie de Góngora ante litteram prácticamente indescifrable-, fue el Calímaco epigramista - y, en general, la Antología Palatina - quien abrió las puertas de mi escritura al alejandrinismo, y desde entonces vivo instalado cómodamente en sus salones».
} 
vida política, que se inicia en 1996 con su designación como director de la Biblioteca Nacional, y seguidamente, en el año 2000, con su desempeño como Secretario de Estado de Cultura, ambos cargos durante la presidencia de José María Aznar (Partido Popular). El abandono de la vida política, entonces, coincide con la publicación de un texto abiertamente polémico que, sin embargo, desplazado más de una década acaba por diluir su belicosidad, acercándose a un texto meramente programático 9 .

Como decíamos antes, "Línea clara” recrea la forma apologética. Habría que explicar que se trata de un caso más cercano a la recusatio calimaquea que a la excusatio de la época augustea, pese a que las relaciones entre poesía y política se encuentran presentes («nuestros versos, incluso la gente que gobierna, / lo que trae consigo que tengamos acceso / al poder y a sus premios y condecoraciones»). El poema, en sintonía con la figura calimaquea, enfrenta dos formas de poetizar diversas, privilegiando una por sobre otra y habilitando un espacio polémico en el que se describe su propia poética.

«Línea clara» dispone un andamiaje que, desde lo sintáctico, hace que el enfrentamiento entre dos líneas estéticas sea evidente. Un encadenamiento de estructuras encabezadas por el verbo «dicen» impone un espacio discursivo - aunque indirecto- que se le atribuye al adversario. De este modo, la primera persona, recubierta de «un plural meramente poético», no hace más que describir las dos posiciones, dejando que el lector — que adopta lo que Eliseo Verón llamó un rol para-destinatario (1987) - comprenda la ironía y se persuada del valor de la propuesta. El dispositivo de la argumentación, por lo tanto, colabora a que el programa poético, por un lado, no sea impuesto de forma autoritaria y por otro, a que se vea envuelto en la tensión de una polémica o, si volvemos a pensar en el retraso de su publicación, en su mera simulación. En todo caso, el discurso indirecto libre acaba por perfilar la presencia de un lector y, en consecuencia, de un par para la comunicación, lo que redunda nuevamente en la presencia de una de las dos posiciones presentadas, tal como queda esbozado en los primeros versos: «Dicen que hablamos claro, y que la poesía/ no es comunicación, sino conocimiento».

El enfrentamiento entre poesía como comunicación y como conocimiento, por lo menos en el ámbito hispánico, tiene su origen en una polémica iniciada en la década del cincuenta. La primera acepción se encuentra estrechamente vinculada con la poesía de corte social que había imperado durante la década del cuarenta y que comprendía al texto poético como un vehículo no problemático de transmisión de contenido de conciencia, y la segunda acepción con otra de corte moderno y europeísta, que valoraba el proceso poético en su dimensión epifánica y gnoseológica (Ferrari 2010: 10) y que habría de imponerse entre las décadas del sesenta y el setenta. Las primeras teorizaciones ${ }^{10}$ sobre la poesía de matiz comunicativo provienen de la publicación, entre noviembre y diciembre de

\footnotetext{
${ }^{9}$ Su ubicación en el cuerpo del libro - recordemos que se trata del primer poema一, habilita esa lectura, en la medida en que funciona como una entrada al texto que anticipa el contenido que se dispondrá a continuación. Esta lectura se asienta, además, en la gran importancia que le otorga a los paratextos y a la organización de los poemas y las secciones.

${ }^{10}$ Ese mismo año, en enero, el poeta Gabriel Celaya en una conferencia titulada «El arte como lenguaje» había lanzado una fórmula que homologaba arte y comunicación: «El arte es comunicación. No hay arte sin dos hombres concretos y precisamente distintos: El autor y el espectador. La presencia de ambos es igualmente indispensable. El arte, en efecto, no está encerrado y como enjaulado en las obras de arte. Pasa a través de estas como una corriente. Consiste precisamente en ese pasar transindividual, en este movimiento retenido pero palpitante que las anima, en ese ser del autor y del espectador uno para otro y en el otro: en ese salir de las fronteras individuales para lanzarse a la búsqueda de un hombre, de un tiempo y de un lugar cualesquiera que nos confirme y nos revele» (Lanz 1993: 194).
} 
1950, de unos aforismos por parte del poeta Vicente Aleixandre en las revistas Ínsulas y Espadaña ${ }^{11}$ La polémica, propiamente dicha, sin embargo, se inicia en 1952 con la publicación del libro Teoría de la expresión poética de Carlos Bousoño, en el que se define la poesía como «comunicación establecida con meras palabras, de un contenido psíquico sensóreo-afectivo-conceptual, conocido por el espíritu como formando un todo, una síntesis» (Bousoño 1998: 22). Esta acepción de la poesía, evidentemente, daba cuenta de una tendencia que se había consolidado en la década previa, a través de la poesía social de autores como Hierro, Celaya u Otero, por nombrar a algunos, y que puede verse claramente reflejada en el contenido de la Antología consultada de la Joven Poesía Española (1952). A esta definición —que Bousoño irá remodelando con el paso de la polémica y las sucesivas ediciones del libro- se le enfrentó el grupo barcelonés, nucleado en la revista Laye. La primera respuesta será del poeta, crítico y editor, Carlos Barral, quien un año después en el número 23 de la mencionada revista inicia una impugnación a la concepción comunicativa de la poesía que había propuesto Bousoño - y con ella a la propuesta social de la Antología consultada - a partir de un ensayo encabezado por un título provocador: "La poesía no es comunicación”. Allí Barral señala que la postura de Bousoño suponía "la preexistencia al poema de un contenido psíquico (...), que pudiera ser explicado idiomáticamente y que es transmitido, por medio de una manipulación estética de la lengua, al lector en el acto de la lectura"(Barral, 1952, p. 24). Por lo tanto implicaba una peligrosa reducción del proceso y del hecho poético, que para Barral se produce tanto en el momento de la creación como en el momento de la recepción, es decir, no constituye un saber previo sino un descubrimiento que se lleva a cabo durante el proceso:

El poeta ignora el contenido lírico del poema hasta que el poema existe. Del mismo modo en la lectura el poema adquiere del lector su total contenido lírico a partir de un esfuerzo de colaboración que vierte sobre él sus vivencias propias y el matiz de su propio mundo lingüístico (1952: 24-25).

La polémica fue animándose con la participación de otros críticos y poetas (Gil de Biedma, Badosa, Valente y Claudio Rodríguez) que poco a poco fueron modelando su respuesta. La función reveladora, epifánica o gnoseológica del poema se replicaría, por lo tanto, en diversas poéticas, como la de José Ángel Valente, quien declararía que "la poesía es (...) antes que cualquier otra cosa, un medio de conocimiento de la realidad" (Guillén Acosta, 2000, p. 31). El impulso de esta poesía, además de buscar abrir la producción española al panorama europeo moderno, implicaba la habilitación de una línea estética especulativa que en los años cincuenta puso en vidriera a las producciones de los poetas implicados en la polémica (Valente, Brines, Barral, Gil de Biedma, etc.), cuyo magisterio, a su vez, abriría un campo de posibilidades para la aparición, en principio, de la ya mencionada generación poética de los setenta —en la que puede leerse, paradójicamente, sin inconvenientes la poesía temprana

\footnotetext{
11 A continuación reproducimos algunos de los aforismos que apuntalaban esta concepción comunicativa de Vicente Aleixandre: «El poeta llama a comunicación y su punto de efusión establece una comunidad humana.» [...] «La Poesía no es cuestión de fealdad o hermosura, sino de mudez o comunicación.» Lanz 1993: 194). La obra de Aleixandre, que en sus comienzos había estado vinculada con la Generación del '27, un movimiento español en sintonía con las principales vanguardias históricas, durante la posguerra y su consecuente "exilio interior" se acercará a la estética verista de la poesía social que había imperado a mediados de siglo.
} 
de Luis Alberto de Cuenca- y luego para el desarrollo de diversas poéticas del silencio o del fragmento a las que se refiere la recusatio luisalbertiana, cuando impugna la poesía de tono «intelectual, abstruso, místico, filosófico». La regularidad de esta línea estética, que supo identificarse, como pudimos apreciar, con el marbete de «poesía del conocimiento», articuló una serie de expectativas, prácticas y fines comunes a las que muchos poetas, luego de la polémica de los cincuenta, se suscribieron. Tan es así que es posible establecer un horizonte bastante preciso sobre el que dicha poética se asentó ${ }^{12}$ y cuáles serían las obras implicadas en esta categorización. De este modo, es posible entender la evidente elisión del sujeto de este "dicen", en la medida en que resulta fácilmente reconocible por un lector de poesía actual. Ahora bien, la elección poética realizada por de Cuenca no puede entenderse bajo ningún aspecto como una vuelta a la poesía social, ni mucho menos como una forma de compromiso político. Por el contrario, debe ser entendida como la búsqueda de un dispositivo verbal que privilegie la función dialógica —es decir, una legibilidad amplia -, la claridad expositiva — sin recaer en la inocencia verista de la poesía social- y la intimidad —entendida como una construcción problemática entre lo biográfico y lo cultural-.

El enfrentamiento que propone Luis Alberto de Cuenca no solamente recae sobre esta polémica; también implica otro recorrido de larga data en la tradición lírica española del siglo XX. La recuperación de los valores («la amistad, la ternura, / la decepción, el fraude, la alegría, el coraje, / el humor y la fe, la lealtad, la envidia,/ la esperanza, el amor...») da cuenta de una rehumanización de los contenidos de la poesía, que obviamente se enfrenta al gesto de "renuncia" que implicaría la poesía como conocimiento ${ }^{13}$. Durante la década del ochenta y noventa, la crítica coincide en que este proceso de rehumanización se hace evidente, sin embargo sus implicancias, lejos de ser las mismas, adquieren diferentes relieves en los poetas del periodo. Marta Sanz Pastor indica que, en todo caso, se trata de una reivindicación del papel del poeta en la sociedad «que se puede concretar en sus obras o en su participación en otros foros de la vida civil o colectiva» (2007: 30). La crítica, además, añade que se pone de manifiesto la vocación de humanizar la palabra poética desde una perspectiva ética, colectiva

\footnotetext{
12 Marta Ferrari, en un texto dedicado a "la poesía del pensamiento", recrea la implicancia de la expresión "poesía del conocimiento": «Pareciera, entonces, que en el denominador "poesía del conocimiento", tal como ha venido siendo utilizado a lo largo de la segunda mitad del siglo XX, está implícita la noción de un saber —averiguar y entender, búsqueda y hallazgo-, positivo en cualquier caso, que se propone sistemáticamente como conquista y aprehensión —son comunes y reiteradas las nociones de "revelación", "develamiento", "profecía", "adivinación”, "valor gnoseológico y epifánico", "acto fundacional", "actividad primigenia" atribuidos al texto poético- de una realidad previa, simultánea o posterior al hecho estético. Un saber cuasi solipsista por oposición al poema organizado en torno a la segunda persona de las estéticas sociales, que radicaliza el subjetivismo a los límites del conocimiento del propio yo. La poesía del conocimiento, entonces, hace referencia en un plano teórico muy general a un tipo de poesía decididamente opuesta a la de corte social-realista, una poesía de clara raigambre romántico-simbolista que se inserta en la tradición de lo sagrado, que se vincula con la antigua identificación entre el poeta y el medium o el poeta-vate, a través de una fe - muchas veces- incuestionable en una palabra que se pretende reveladora y trascendente, desatenta del lector por lo que implica de dicción hermética, deudataria de ese indagar en "lo oscuro", en el "misterio", en "lo numinoso".» (2010: 13).

13. El problema de la deshumanización de la poesía nos remite al célebre libro de Ortega y Gasset, La deshumanización del arte (1925), en el que la visión interpretativa de las vanguardias históricas había abierto un filón de lectura para la producción experimental de generación del '27. La generación posterior, bajo la acogida de la República y la posterior Guerra Civil, había acusado un proceso de rehumanización que acabó derivando en la hegemonía de la estética verista de la poesía social.
} 
y social, que en última instancia lo que busca es romper con el solipsismo autorreferencial en el que había recaído la poesía novísima y abrir un espacio para la intimidad entendida como una construcción histórica. En el caso particular de Luis Alberto de Cuenca, habría que decir que esta rehumanización puede comprenderse, principalmente, a partir de la búsqueda de legibilidad, entendida como una construcción discursiva o techné que habilite un intercambio horizontal -aunque fuera en su superficie- de la palabra poética, que la acerque a otros géneros a partir del reconocimiento de un mismo régimen ficcional.

La construcción de un espacio “colectivo", a partir de la publicación de La caja de Plata, implica el diseño de un lectorado distinto, menos restringido que el de su obra previa. Su poesía, en efecto, a partir de entonces, va a apostar por un repertorio poético que se confunde intencionalmente con el lenguaje cotidiano. La recuperación del coloquialismo y su carácter figurativo harán en efecto que la dicción poética no se diferencie de otros géneros literarios - más prosaicos- como la narrativa, pero tampoco de los discursos del periodismo y de la política, lo que en consecuencia redunda en una participación activa - y consecuente consagración - de la figura autoral en la vida social:

Dicen que hablamos claro, y que nos repetimos
de lo claro que hablamos, y que la gente entiende
nuestros versos, incluso la gente que gobierna,
lo que trae consigo que tengamos acceso
al poder y a sus premios y condecoraciones,
ejerciendo un servil e injusto monopolio.

Este "hablar claro", entendido como una apuesta a la ampliación del público, además, habilita una serie de homologaciones y cruces que se encuentran condensados en la recusatio del poema. En principio, la acusación del hablar claro de la que se defiende el poeta apunta a la economía linguiística («nos repetimos de lo claro que hablamos») y deja en evidencia una superposición entre habla y escritura. Como ya se dijo antes, la dicción poética en la obra de Luis Alberto de Cuenca, a partir de la década de los ochenta, se va a diferenciar en poco del habla coloquial. Uno de los críticos que más se ha dedicado a la obra del madrileño, Juan José Lanz observa en este coloquialismo un rasgo fundamental de este periodo de su obra. Se trataría de un desplazamiento - sumamente significativoen la concepción del hecho poético, a partir del cual el fenómeno de lo poético pasaría de ser un fenómeno lingüístico —entendido, tal como lo había planteado el estructuralismo, como una desviación de la norma- a ser fenómeno pragmático, en el que la poesía surja de un juego de complicidades y de sobreentendidos entre elementos convencionales. En otras palabras, la poesía para de Cuenca no supondría un empleo de un lenguaje diferente (un divorcio entre lenguaje poético y lenguaje cotidiano), sino la creación de un contexto enunciativo específico; sería, por lo tanto, menos dicción que ficción (1996: 23).

Este coloquialismo, por otra parte, no debe entenderse como una vuelta a los usos de las formas orales, tal como la entendieron los poetas sociales, para quienes este procedimiento habilitaba una conexión entre sujeto poético y sujeto político, ni tampoco puede ser atribuido a un repentismo en la medida en que es fruto de una construcción textual sumamente meditada. En efecto, la poesía de Luis 
Alberto de Cuenca presenta un minucioso simulacro del repertorio coloquial, que afincado en un patrón métrico regular (en la recusatio, por ejemplo, el endecasílabo blanco) en el que escasean las rimas y con una organización silogística de la información, produce el efecto de este «hablar claro». El coloquialismo, de este modo, funciona como una superficie por la que circulan contenidos, referencias y complicidades, y que pese a su apariencia sencilla esconde una serie de sutilezas y dificultades que habilitarán diversos modos de lectura. El cruce entre habla y escritura, por lo tanto, implicará la construcción de un universo de legibilidad de diversos niveles, para diversos lectores, es decir, un espacio más amplio que busca romper con una producción poética confeccionada solamente para iniciados.

En segundo lugar, el hablar claro impone una homologación entre las denominadas «alta» y «baja» culturas, hecho que se hace evidente con la aparición de Tintín en el final. Estos cruces, además, pueden observarse en la organización de los últimos versos que desde lo formal recuperan la tradición culta del epigrama, con sus finales incisivos, y que al mismo tiempo, se conectan con las estructuras narrativas de la literatura de masas, con sus finales abiertos (cliffhanger). El entrañable personaje de Hergé, por su parte, inmediatamente se asocia al título del texto, en la medida en que "Línea clara" es el nombre que recibió la producción de la célebre Escuela historietística de Bruselas de la que surgió el joven periodista y su perro Milú. Por lo tanto, desde un punto de vista enunciativo, la respuesta a la poesía del conocimiento - en términos casi épicos - se encuentra en el repertorio masivo y, más particularmente, en la historieta. De este modo, a una literatura de tono transcendental, «intelectual, abstruso, místico, filosófico» Luis Alberto de Cuenca le enfrenta un corpus destinado a la diversión, el pasatiempo, cuyo estatuto literario ha sido constantemente puesto en duda.

Esta amplia comprensión de las tradiciones que ostensiblemente borra las jerarquías entre alta y baja cultura se encuentra con matices en toda su obra ${ }^{14}$. Respecto de esta operatoria, habría que observar que si bien la aparición de elementos propios de la cultura masiva no es una novedad durante la década del noventa, lo que resulta sumamente llamativa es la comprensión de la cultura erudita a través de una mirada masiva. En otras palabras, si la irrupción de estos elementos durante la década del sesenta y setenta había estado dada por lo que Javier Letrán llamó una «elitización de las referencias a la cultura popular"》 (Letrán 2005: 73), que implicaba una ruptura de sus modalidades de lectura en aras de un acercamiento a la alta literatura (leer la historieta, por ejemplo, como un texto épico), a

\footnotetext{
${ }^{14}$ El poema "Homo homini lupus", por ejemplo, intersecta la famosa frase del Leviatán de Hobbes con el cine de licantropía: «No venimos del mono. Lo siento, señor Darwin. / Somos lobos sin pelo que andamos por el mundo/ en posición erguida, pero con esos ojos / crueles e inyectados en sangre y esas fauces/ repletas de cuchillos con que los lobos viajan / por el bosque del caos, paidófilos y arteros. En nuestro más añejo depósito de mitos / vive, junto al vampiro, el peludo hombre lobo. / De la misma manera que Hyde domina a Jekyll, / la bestia que se agita en las oscuridades / de nuestro yo termina por imponerse al ángel / que fuimos no sé cuándo (o no lo fuimos nunca), / y, aunque nos disfracemos de tiernos corderillos / o de dulces abuelas por puro pasatiempo, / somos, allá en el fondo, lobos depredadores/ que aúllan a la Luna en la terrible noche / de la razón, allí donde habitan los monstruos / y tienen su refugio las negras pesadillas. / Hobbes lo tuvo muy claro, y uno, que es un fanático / del cine de licántropos, lo ratifica ahora: / homo homini lupus.» (de Cuenca 2002: 89)
} 
partir de la década del ochenta lo que podemos observar es la masificación de la cultura de elite, es decir, la adopción no solamente de un sistema referencial proveniente de los massmedia sino también de sus formas de lectura (leer la épica, por ejemplo, como un texto historietístico). El hablar claro, en este sentido, apuntaría a la equiparación posmoderna de los códigos de la cultura erudita con los de la cultura de masas, es decir, a la conformación de un espectro cultural amplio, en el que dichas jerarquías queden anuladas, habilitando cruces y relevos, al mismo tiempo novedosos e inteligibles.

Para finalizar, habría que decir que este hablar claro impone una última homologación. Se trata de un interesante juego de palabras entre este hablar claro y la "línea clara" antes mencionada, es decir, entre palabra poética e imagen. La expresión "línea clara" o "ligne claire" fue acuñada por Joost Swarte en 1977 y su tradición se remonta al estilo cultivado por el cómic franco-belga, —en particular por la denominada "Escuela de Bruselas"—, cuyos representantes más conocidos son Edgar P. Jacobs (Blake y Mortimer), Jacques Martin (Alix), Bob de Moor (Barelli) y Herge (Tintín). En términos generales, esta línea estética se destaca por el trazo limpio, continuo e idéntico, por los colores planos, sin sombras ni volúmenes, y por el realismo y el detalle. En sus comienzos, en la década del veinte, significaba una "vuelta al orden", una aminoración del entusiasmo vanguardista y un regreso a lo clásico, al dibujo ingresiano, preocupado por la línea, aunque sin renunciar al lenguaje de la modernidad (Castillo Cáceres, 2011, p. 16). La apropiación del término por parte de Luis Alberto de Cuenca implica una comprensión pictórica de su poesía. En otras palabras, el dispositivo poético que describimos previamente - aquel que apuesta a la figuración y la claridad expositiva, y que rompe con las diferencias entre la cultura erudita y la popular o masiva, confundiendo sus modos de lectura y sus universos referenciales-, puede ser fácilmente asociado al presente en los álbumes de Tintín. La relación entre imagen y texto, por su parte, nos conduce a un problema teórico de larga data, que no viene al caso de la recusatio ${ }^{15}$. Lo que sí es importante establecer es que esta aproximación propone otro enfrentamiento con la posición adversaria, a partir del cual el poeta se afirma como poeta de la línea o trazo claro - es decir de la imagen - en contraposición a los poetas de la denominada "generación del lenguaje"16. A grandes rasgos, podríamos indicar, siguiendo nuevamente a Marta Sanz Pastor, la presencia de esta última línea estética — que puede ser asociada a la descripción realizada por el poeta - que se remonta a la polémica de los años cincuenta antes descrita y en la que convivirían autores de diversas generaciones. Se trata de una estética que, respaldada en el giro lingüístico operado por la irrupción del estructuralismo, gozó de amplia popularidad entre los poetas que encontraban en ella una salida —de múltiples articulaciones tradicionales, por cierto- de la poesía social. Habría que

\footnotetext{
${ }^{15}$ El problema al que nos enfrenta la poesía de Luis Alberto de Cuenca es el de la relación de las imágenes con los textos, temática que tiene sus antecedentes en tópicos clásicos como el horaciano ut pictura poiesis y que formas intermediales como las del cómic o el cine — tan caras por cierto al poeta español— han vuelto a poner bajo la lupa teórica (Rajewsky: 2005). El arco de interpretaciones de esta relación, además, resulta amplísimo y va desde la afirmación de que la poesía, como pensaba Simónides de Ceos, «es pintura que habla y la pintura, poesía muda» hasta la de Sussane Langer, para quien no existirían en estos encuentros «matrimonios felices, solo violaciones exitosas», es decir, una disputa y una imposición de una sobre otra (Mitchell: 2016).

${ }^{16}$ Algo que resulta sumamente llamativo es el hecho de que dicha categorización fue empleada por el propio de Cuenca para referirse a su producción durante la década del setenta.
} 
decir, además, que la relación de la poesía con la imagen, tal como sostiene Margaret Persins en su artículo sobre la poesía ekfrástica, es amplia y cuantiosa en la poesía española de los setenta (1991). Sin embargo, esta lectura de la imagen se encuentra amparada en un horizonte estructuralista que la comprende como un texto, es decir, a partir de un aparato interpretativo cuyo modelo es únicamente el verbal. Por el contrario, el movimiento que plantea Luis Alberto de Cuenca comprende una operatoria contraria, que puede ampararse en lo que Thomas Mitchell en su libro Teoría de la imagen denominó el giro pictorial (2009). Para el especialista estadounidense, este giro consistiría en un cambio de paradigma, que posiciona a la imagen, a sus modos de representación e interpretación, y a sus aparatos en el centro de la escena (2009: 23). La línea clara, entonces, viene a declarar una suerte de «giro pictorial» en la poesía de Luis Alberto de Cuenca, en confrontación al giro lingüístico acusado durante el momento de auge del estructuralismo, que en el panorama de la poesía española se hace evidente a partir de la segunda mitad del siglo XX, con la aparición de estas poéticas del conocimiento antes descritas. El "hablar claro" que presenta la recusatio, entonces, debe ser leído como la palabra del otro, del adversario, en un sentido estricto, y debe ser contrastado con el título, "Línea clara". Esta sutil diferencia, propiciada por la estructura de la recusatio, viene a afirmar dos posiciones enraizadas en presupuestos teóricos muy diversos: la del modelo lingüístico y la del modelo visual. En otras palabras, la valoración por un lado de la lectura, de lo verbal, encauzado en esa acusación del hablar claro y la valoración de lo visual, de la imagen, de la línea o trazo, por el otro, presente en el título.

\section{Conclusión}

Para finalizar este trabajo es importante destacar la persistencia histórica de la recusatio y al mismo tiempo su capacidad, como figura retórica, de adecuarse a las diversas necesidades de los poetas y sus contextos de producción. Desde la teorización poética de Calímaco en contra de las críticas de los Telquines, pasando por las astucias de Horacio para evitar el epos heroico que le exigía Mecenas, hasta llegar en el siglo XXI a la enunciación simuladamente polémica que propone Luis Alberto de Cuenca, la forma apologética probablemente haya sobrevivido porque la reflexión en torno al propio poetizar no puede pensarse por fuera del campo estético. Es por esta razón que este topos resulta tan interesante: porque no solamente sirve para comprender la poética de un autor sino además porque permite describir las resistencias a las que esta se enfrenta, dejando en claro que todo texto programático es, al fin y al cabo, una respuesta, el pie para comenzar o continuar una polémica. 
De Calímaco a Tintín: sobre el uso de la recusatio en un poema de Luis Alberto de Cuenca

\section{Referencias bibliográficas}

Agudo, Á. C. (2009): «Musa Levis/Blanda Musa: concisión y sutileza como presupuesto poético elegíaco desde Calímaco al Renacimiento», Florentia Iliberritana, 20, pp. 39-77.

Álvarez Hernández, A. (1997): La poética de Propercio: autobiografía artística del Calímaco romano. Assisi, Escuela Properziana de Subasio.

BAGUÉ Quílez, L. (2003): «La recuperación del sentido clásico en la última poesía española», Hesperia. Anuario de Filología Hispánica, 4, pp. 27-41.

BARRAL, C. (1952): «La poesía no es comunicación», Laye, 23, pp. 23-26.

BiCKEL, E. (1982): Historia de la literatura romana. Trad. J. M. Díaz-Regañón López. Madrid, Gredos.

Bousoño, C. (1998): Teoría de la expresión poética. Madrid, Gredos.

BRIOSO, M. (1987): Los epigramas literarios de Calímaco. Madrid, Gredos.

CALÍMACO. (1980): Himnos, epigramas y fragmentos. Trad. Luis Alberto de Cuenca. Madrid, Gredos.

CASTILlo CÁCERES, F. (2011): Tintín-Hergé: una vida del siglo XX. Madrid, Fórcola.

De CuencA, L. A. (2006): Poesía 1979-1996. Ed. Juan José Lanz. Madrid, Cátedra.

(2002): Sin miedo ni esperanza. Madrid, Visor.

_ (2006): La vida en llamas. Madrid, Visor.

De Romilly, J. (2016): Compendio de Literatura griega. Trad. J. F. Polo Arrondo. Madrid, San Dámaso.

D’ORS, E. (1997): «Última poesía española, por el sentido común al aburrimiento». Nueva Revista, 7/50, en http://www.nuevarevista.net/articulos/ultima-poesia-espanola-por-el-sentido-comun-alaburrimiento (última consulta: 18-11-2017).

FERRARI, M. B. (2010): Vivir con las palabras: poesía y pensamiento en Carlos Marzal. Mar del Plata, EUDEM.

FERRATÉ, J. ed. (1996): Los griegos arcaicos. Barcelona, Qaderns Crema.

Guillén Acosta, C. ed. (2000): Poesía Española (1935-2000). Barcelona, Casals.

HinOJO ANDRÉs, G. (1985): «Recusationes...?», Nova Tellus, 3, pp. 75-89.

LANZ, J. J. (1993): Introducción al estudio de la generación poética española de 1968. Madrid, Universidad Complutense de Madrid.

(1996): «Luis Alberto de Cuenca». en L. A. DE CuencA, Poesía. Madrid, Cátedra.

LETRÁn, J. (2005): La poesía postmoderna de Luis Alberto de Cuenca. Sevilla, Renacimiento.

MitChell, W. J. T. (2009): Teoría de la imagen. Madrid. Akal.

Pedernera, S. (2011): «Dulcis cantus en la Oda II, 12 de Horacio», Auster, 16, pp. 67-78.

PERsin, M. (1991): «La imagen del / en el texto: el ékfrasis, lo postmoderno y la poesía española del siglo XX». en B. CIPliJauskaitÉ, ed., Novísimos, postnovísimos, clásicos. La poesía de los 80 en España. Madrid, Orígenes.

Romero y Cordero, R. (1955): Horacio. Quito, Casa de la Cultura Ecuatoriana. 
254 | Tropelías. Revista de Teoría de la Literatura y Literatura Comparada, 30 (2018) Facundo Giménez

SANZ PASTOR, M. ed. (2007): Metalingüísticos y sentimentales: antología de la poesía española 19662000: 50 poetas hacia el nuevo siglo. Madrid, Biblioteca Nueva.

Sequeiros, V. A. (2009): «Horacio y la recusatio de la elegía amorosa», Auster, 14, pp. 47-62.

VERÓN, E. (1987): «La palabra adversativa. Observaciones sobre la enunciación política», en El discurso político. Lenguajes y acontecimientos. Buenos Aires: Hacette. pp. 11-26.

VILLENA, L. A. de. (1992): Fin de siglo (El sesgo clásico en la última poesía española). Madrid: Visor. 